\title{
EDITORIAL
}

\section{LAS COSAS "A LA CHILENA" Y NUESTRO DERECHO PARA EL AÑO 2011}

Gracias a la gesta de los treinta y tres rescatados de la mina San José, a la eficiencia y preocupación con la cual se consiguió traerlos de vuelta a sus casas, y a un casual aporte internacional, el año que finaliza se caracterizó por identificar el hacer las cosas "a la chilena" con un modo virtuoso, productivo y oportuno de actuar, lo cual sin duda fue una contribución a nuestra imagen-país y al espíritu nacional, afectado meses antes por las catástrofes naturales también vividas este año 2010.

Nuestra tierra, aunque resulte manido decirlo, es un paraíso de contrastes en el cual, en espacio relativamente breve de tiempo, tuvimos desolación y esperanza, incertidumbre y confianza, heroísmos y bajezas, éxitos y derrotas. Como la vida social, la política y las comunicaciones son sin duda muy dinámicas, para muchos las buenas nuevas y los logros de alguna manera nos instalaron mentalmente en el progreso y en la convicción que, de aquí en adelante, ya no caben chapuzas, debilidades ni fallas en nuestro actuar y que, trátese de los órganos públicos o de lo particulares, estaremos constantemente imbuidos en claves solidarias, humanas y efectivas respecto de los desafíos venideros.

El optimismo es un buen recurso cuando se asocia a una fe genuina y a un compromiso auténtico por un actuar debido, pero corre el riesgo de transformarse en una actitud ramplona, soberbia o irresponsable cuando se mueve en la pura subjetividad, las ganas y los efectos publicitarios. Por tal razón, nuestra orgullosa frase de hacer las cosas "a la chilena" puede transformarse en un sello de calidad nacional, pero en la medida que se proyecte al hacer de cada uno de nosotros y que ello suceda en un clima de realismo y responsabilidad respecto de nuestros recursos, carencias y compromisos.

En esa perspectiva, nuestro Derecho del año 2011 no será el paradigma de desarrollo o madurez jurídica sencillamente porque las encuestas nos hablen de más tribunales, proyectos de ley o suscripción de tratados internacionales, sino porque su mirada se corresponda con nuestros temas pendientes y con la necesaria solución de problemas, algunos crónicos y otros sobrevinientes.

Respecto de esos asuntos y tareas pendientes, nos parece importante enfatizar cuatro, aclarando desde ya a nuestros lectores que estos no excluyen en lo absoluto a otros de tanto o mayor interés que puedan considerarse también en esta lista.

El primero, puesto allí quizás por ser más sensible y conmovedor, es la situación de nuestros niños. Si bien mucho se ha escrito y legislado acerca de su protección, del superior interés del menor y de los deberes de padres y cuidadores ante derechos reconocidos universalmente, aún restan espacios grises y preocupantes, que van desde los menores dedicados a la delincuencia o asiduos practicantes de matonaje escolar, hasta pequeñas víctimas de redes de prostitución, maltrato infantil 0 descuidos 
inenarrables. No conseguimos aún hacer de nuestra patria un lugar seguro para los niños, ni hemos generado mecanismos de control suficientes para evitar que lactantes sean olvidados a su suerte en salas de clase, transportes escolares o jardines con puertas mal cerradas. A estas situaciones solemos responder abrumados justificando los hechos por la ausencia de malicia de los involucrados o por las leyes del azar, cuando en realidad no se trata de alentar cazas de brujas, sino de evitar desprotecciones o abusos evidentes, independientemente de las personas que los causen.

El segundo tiene que ver con el modo de entender e interpretar los derechos de las personas. Vivimos una activa creación jurisprudencial de contenidos garantísticos que curiosamente ha superado con mucho a la doctrina, pero a diferencia de esta, los fallos tienen efectos concretos y donde abren puertas y prerrogativas, cierran otras e imponen obligaciones. En ese escenario, que termina intermediando contratos, modificando sistemas o abriendo grandes líneas interpretativas, dable es esperar de los sentenciadores menos romanticismo y más realidad, de modo tal que sus buenas intenciones no terminen engendrando productos jurídicos de dudosa bondad o que terminen dejando a los derechos más debilitados que al comienzo, como está ocurriendo por ejemplo en el ámbito de los derechos económicos y sociales.

El tercero se relaciona con las reformas constitucionales. Bien por la mutación constitucional de la mano con la evolución jurídica y las reflexiones contemporáneas, ello permite institucionalizar cada día más nuestra Carta Fundamental y vivenciarla; pero cuidado con dejar el pacto social a los vientos que corren en uno u otro sentido o las veleidades personales de partidos o personeros. No se trata aquí de tratar de cambiar lo mal hecho, sino de hacerlo una vez y bien.

El último es atingente a la relación de nuestro Derecho con los medios de comunicación. Sin duda, estos últimos son el mecanismo mediante el cual sabemos casi todo lo que ocurre y tenemos noticia de hitos incluso jurídicos, pero ello no excusa a los poderes creadores de la norma, intérpretes de esta o administradores de justicia a realizar las labores encomendadas, hacerlo transparentemente y dar cuenta de sus actos. Lo contrario no es una concesión graciosa sino una falta de servicio.

Junto con desear a nuestros lectores, autores, colaboradores y equipo una hermosa Navidad, les transmito estas reflexiones, en la esperanza que hacer las cosas a la chilena sea en los próximos meses, también, un reflejo de responsabilidad jurídica y de excelencia de los operadores de nuestro ordenamiento jurídico.

Directora

ÁNGELA ViVANCO MARTÍNEZ 